\title{
Effect of autologous platelet rich plasma on anti-mullerian hormone and antral follicle count in sub fertile women with poor ovarian reserve
}

\author{
Muhammad J. Uddin ${ }^{1}$, Jesmine Banu${ }^{1}$, Shakeela Ishrat ${ }^{1 *}$, Sabiha Sultana ${ }^{1}$, Serajoom Munira $^{1}$, \\ Mehnaz M. Shume ${ }^{1}$, Sheikh F. Huda ${ }^{2}$
}

\begin{abstract}
${ }^{1}$ Department of Reproductive Endocrinology and Infertility, ${ }^{2}$ Department of Gynaecological Oncology, Bangabandhu
\end{abstract} Sheikh Mujib Medical University, Dhaka, Bangladesh

Received: 18 December 2021

Accepted: 03 January 2022

\section{*Correspondence:}

Dr. Shakeela Ishrat,

E-mail: shakeelaishrat@bsmmu.edu.bd

Copyright: ( $)$ the author(s), publisher and licensee Medip Academy. This is an open-access article distributed under the terms of the Creative Commons Attribution Non-Commercial License, which permits unrestricted non-commercial use, distribution, and reproduction in any medium, provided the original work is properly cited.

\begin{abstract}
Background: Ovarian aging may be reversible. Platelet rich plasma (PRP) has growth factors that promote cellular proliferation and folliculogenesis. Recently published studies and case reports suggest that ovarian rejuvenation can be done by PRP treatment. The objective of the study was to evaluate the effect of platelet rich plasma on ovarian reserve markers such as anti mullerian hormone (AMH) and antral follicle count (AFC) in sub fertile women with poor ovarian reserve (POR).

Methods: The self-controlled quasi experimental study was carried out on 29 sub fertile women with poor ovarian reserve. They were selected for laparoscopic tubo-peritoneal evaluation as they could not afford in vitro fertilization. During laparoscopy, $5 \mathrm{ml}$ of pre prepared autologous PRP was injected into each ovary. Post-PRP AMH and AFC were measured at every cycle for a period of at least three (3) months and compared with base line values.

Results: Mean age of participants was $35.9 \pm 3.2$ years. Baseline AMH was $0.31 \pm 0.17 \mathrm{ng} / \mathrm{ml}$ and baseline AFC was $3.41 \pm 0.73$. AMH was raised on first, second and third cycle from base line values in $58.62 \%, 86.21 \%$ and $91.30 \%$ of the study population respectively. AMH changes in all three cycle were statistically significant. Pregnancy occurred in three $(10.34 \%)$ women during the study period.

Conclusions: The injection of autologous PRP into human ovaries is a safe procedure to improve ovarian reserve markers (AMH and AFC) in women with POR.
\end{abstract}

Keywords: Poor ovarian reserve, Platelet rich plasma, Anti-mullerian hormone, Antral follicle count

\section{INTRODUCTION}

Poor ovarian reserve (POR) indicates a reduction in quantity and quality of ovarian follicular pool in women of reproductive age group. ${ }^{1}$ Majority cases are poor or nonresponder, typically need higher doses of costly ovarian stimulation regimes in in vitro fertilization (IVF) cycles. Once the ovary fails to respond to stimulation, ovum or embryo donation is the only treatment modality recommended. The scientific research for the management of ovarian insufficiency was based on the belief that aging ovaries are not amendable to renewal. ${ }^{2}$ Studies with mice in 2004 challenged the idea of a fixed ovarian reserve. ${ }^{3}$
Later many studies showed that ovarian aging may be reversible. ${ }^{4,5}$

Platelet contains more than 30 bioactive proteins, having important role in hemostasis and tissue healing. Growth factors include platelet derived growth factors (PDGFs), transforming growth factor beta (TGF-B), vascular endothelial growth factors (VEGFs), epidermal growth factors (EGFs), fibroblast growth factors (FGFs), insulin like growth factors (IGFs) and some others stored in granules. ${ }^{6,7}$ They are actively secreted by platelets and bind to trans-membrane receptors of target cells including mesenchyme stem cells, osteoblasts, fibroblasts, 
endothelial cells and epidermal cells. These agonists bound to trans-membrane receptors, activate an intracellular signal protein that causes gene expression and directs cellular proliferation. Platelet rich plasma (PRP) is composed of serum containing platelet concentration of more than 10,00,000 platelets per cubic microlitre. Autologous PRP is prepared from autologous human fresh whole blood collected from the peripheral vein of the same patient on the day of instillation just one hour prior to procedure. ${ }^{8}$ PRP has growth factor concentrations three to five times greater than plasma, promoting cellular proliferation and folliculogenesis. PRP is expected to have beneficial effects on ovarian reserve.

Callejo et al first reported the case of injecting PRP in the transplanted frozen-thawed ovarian tissue. ${ }^{9}$ Pantos et al showed that ovarian rejuvenation and folliculogenesis reactivation occurred in peri-menopausal women after autologous PRP treatment. ${ }^{10}$ Sills et al extended PRP application to ovarian tissue of women with POR; evidence of improved ovarian function was noted in all as early as two months after treatment. ${ }^{11}$

Salih et al conducted a randomized clinical trial to show significant increase in AMH level in Sudanese subfertile women following laparoscopic ovarian autologous PRP injection. ${ }^{12}$ Melo et al investigated, in a non-randomized comparative study in Venezuela, the impact of three cycles monthly intra-cortical ovarian PRP injections on ovarian reserve markers. ${ }^{13}$ Women treated with PRP experienced a significant improvement in follicle stimulating hormone (FSH), AMH and antral follicle count (AFC). Sfakianoudis et al conducted four pilot studies in Greece regarding PRP application in women with POR, premature ovarian insufficiency, peri-menopause and menopause. ${ }^{14}$ A significant improvement of the hormonal profile and the ovarian reserve status was noted in all the four groups, along with improved intracytoplasmic sperm injection (ICSI) cycle performance after PRP injection. These recently published studies and case reports suggest that new eggs could be produced, or ovarian rejuvenation could be done by PRP treatment.

As ovarian reserve markers anti mullerian hormone $(\mathrm{AMH})$ and trans-vaginal sonographic measurement of AFC are mostly established. AMH is a growth factor produced in the granulosa cells of preantral and early antral follicles (2-6 mm). POR is suspected when AMH and AFC is low. ${ }^{15}$

The third party reproduction as ovum or embryo donation is not religiously or psycho-socially acceptable in many countries like Bangladesh. Intra-ovarian injection of autologous PRP may be an alternative experimental treatment option to improve ovarian reserve markers in women with POR. The study was undertaken with the objective to evaluate the effect of PRP on ovarian reserve markers such as AMH and AFC in sub fertile women with POR.

\section{METHODS}

After obtaining approval of institutional review board, this self-controlled quasi experimental study was carried out in the department of reproductive endocrinology and infertility, Bangabandhu Sheikh Mujib Medical University (BSMMU), Dhaka from July 2019 to December 2020.The study population were the diagnosed cases of sub fertile women with POR selected for laparoscopic tuboperitoneal evaluation during the study period. A total of 29 women were selected by convenient sampling. The inclusion criteria were women aged between $30-45$ years, $\mathrm{AMH} \leq 0.5 \mathrm{ng} / \mathrm{ml}, \mathrm{AFC} \leq 4$ in both ovaries, POR in at least one cycle of gonadotropin stimulation, selected for laparoscopic tubo-peritoneal evaluation as they could not afford or agree to IVF. The exclusion criteria were premature ovarian failure (POF) due to genetic or chromosomal abnormality, recent chemotherapy or radiotherapy, previous history of bilateral removal of ovary, current or ongoing anticoagulant use. After full explanation of the study procedure informed written consent was taken from each participant.

Serum AMH levels were measured with use of an enzymelinked immunosorbent assay (ELISA) kit (AMH Gen II ELISA: Beckman Coulter and R \& D Automated Systems). AFC was defined as those measuring 2-10 mm in largest mean diameter on 2-dimentional transvaginal ultrasound on $\mathrm{D}_{2-5}$ of menstrual cycle. We used the cut-off value of 4 follicles in both ovaries. AFC was detected using GEHC LOGIC P7 medical ultrasonography machine with a $7.5 \mathrm{MHz}$ vaginal transducer by the same investigator on $\mathrm{D}_{2-5}$ of menstrual cycle. After counselling and taking informed written consent and pre anesthetic checkup, laparoscopic tubo-peritoneal evaluation under general anesthesia was done. During laparoscopy, $5 \mathrm{ml}$ of pre prepared autologous PRP was injected into each ovary.

\section{Autologous PRP preparation}

This began with the insertion of a $21 \mathrm{G}$ butterfly needle into median cubital vein in order to obtain $30 \mathrm{ml}$ of fresh whole blood into the $\mathrm{CBC}$ tube (6 in number) containing ethylene diamine tetra acetic acid (EDTA).The white blood cells and platelets were separated from the red blood cells and serum by centrifugation for 10 minutes at 1000$1200 \mathrm{rpm}$. Bottom layer consisted of RBCs, buffy coats in middle, and PRP in top. Supernatant top layer was aspirated as PRP and was ready to use. From $30 \mathrm{ml}$ of venous blood $10 \mathrm{ml}$ of PRP was obtained. The preparation of PRP needed less than one hour of time.

\section{The follow up}

In order to monitor the effect of platelet rich plasma (PRP) injection into the ovary, AMH and AFC were measured at four weeks intervals in women who did not menstruate and in menstruating women $\left(\mathrm{D}_{2-5}\right)$ for a period of at least three (3) months. 


\section{Statistical analysis}

Statistical analysis was carried out by using statistical package for social science (SPSS) version 23.0 for Windows (SPSS Inc, Chicago, Illinois, USA).

Paired t-test was done to estimate the changes. Confidence interval was $95 \%$ and $\mathrm{p}$ value $<0.05$ was considered as significant.

\section{RESULTS}

Out of the twenty nine (29) participants, three $(10.34 \%)$ became pregnant during study period and dropped out from monitoring after second cycle. Another three (3) participants dropped out from third follow up due to COVID-19 crisis. Twenty three (23) participants completed third follow up and twenty nine (29) participants completed second follow up. The mean age was $35.9 \pm 3.2$ years.

Table 1: Demographic characteristics of the study participants $(n=29)$.

\begin{tabular}{|c|c|c|}
\hline $\begin{array}{l}\text { Demographic } \\
\text { characteristics }\end{array}$ & Frequency & $\begin{array}{l}\text { Percentage } \\
(\%)\end{array}$ \\
\hline \multicolumn{3}{|l|}{ Age of the patients (in years) } \\
\hline $30-35$ & 16 & 55.17 \\
\hline $36-40$ & 11 & 37.93 \\
\hline $41-45$ & 2 & 6.90 \\
\hline Total & 29 & 100 \\
\hline \multicolumn{3}{|l|}{ Mean \pm SD: $35.90 \pm 3.2$} \\
\hline \multicolumn{3}{|l|}{ Socio economic status } \\
\hline $\begin{array}{l}\text { Lower middle } \\
\text { (6827.79-26857.99 Taka) }\end{array}$ & 18 & 62.07 \\
\hline $\begin{array}{l}\text { Middle } \\
\text { (26858.00-83018.22 Taka) }\end{array}$ & 10 & 34.48 \\
\hline High> (83018.22 Taka) & 1 & 3.45 \\
\hline Total & 29 & 100 \\
\hline \multicolumn{3}{|l|}{ Occupational status } \\
\hline Housewife & 19 & 65.52 \\
\hline Service & 10 & 34.48 \\
\hline Total & 29 & 100 \\
\hline \multicolumn{3}{|l|}{ Educational status } \\
\hline Illiterate & 0 & 0 \\
\hline Below SSC & 11 & 37.93 \\
\hline SSC & 6 & 20.69 \\
\hline HSC & 4 & 13.79 \\
\hline Graduate and above & 8 & 27.59 \\
\hline Total & 29 & 100 \\
\hline \multicolumn{3}{|l|}{ Habitat } \\
\hline Urban & 18 & 62.10 \\
\hline Rural & 11 & 37.90 \\
\hline Total & 29 & 100 \\
\hline
\end{tabular}

Socio economic status (SES) was defined according to new country classification by monthly income level submitted by World Bank Data on FRI 07/01/2016.
Almost two-third (62.07\%) of the participants were from lower middle class. The mean body mass index (BMI) was $23.5 \pm 3.3 \mathrm{~kg} / \mathrm{m}^{2}$. More than two-third $(68.97 \%)$ of the study population had primary sub-fertility. Mean duration of infertility was $6.80 \pm 3.0$ years. Table 1 describes the demographic and Table 2 describes the clinical characteristics of the study population.

Table 2: Clinical characteristics of the study participants $(\mathbf{n}=29)$.

\begin{tabular}{|c|c|c|}
\hline Clinical characteristics & Frequency & $\begin{array}{l}\text { Percentage } \\
(\%)\end{array}$ \\
\hline \multicolumn{3}{|l|}{ Types of infertility } \\
\hline Primary & 20 & 68.97 \\
\hline Secondary & 9 & 31.03 \\
\hline \multicolumn{3}{|c|}{ Duration of infertility (years) } \\
\hline$<5$ & 11 & 37.93 \\
\hline $5-10$ & 15 & 51.72 \\
\hline$>10$ & 3 & 10.35 \\
\hline \multicolumn{3}{|c|}{ Mean \pm SD: $6.80 \pm 3.0 ;$ range (min-max): $2-14$} \\
\hline \multicolumn{3}{|c|}{ Menstrual pattern (last 12 months) } \\
\hline Normal cycle & 26 & 89.66 \\
\hline $\begin{array}{l}\text { One episode of } \\
\text { anovulatory bleeding }\end{array}$ & 3 & 10.34 \\
\hline $\begin{array}{l}\text { Two episodes of } \\
\text { anovulatory bleeding }\end{array}$ & 0 & 0 \\
\hline $\begin{array}{l}>\text { Two episodes of } \\
\text { anovulatory bleeding }\end{array}$ & 0 & 0 \\
\hline Total & 29 & 100 \\
\hline \multicolumn{3}{|c|}{ Family history of early menopause } \\
\hline Yes & 2 & 6.90 \\
\hline No & 27 & 93.10 \\
\hline Total & 29 & 100 \\
\hline \multicolumn{3}{|l|}{ BMI $\left(\mathrm{kg} / \mathrm{m}^{2}\right)$} \\
\hline Underweight $(<18.5)$ & 3 & 10.34 \\
\hline Normal range (18.5-24.9) & 14 & 48.29 \\
\hline Overweight (25-29.9) & 9 & 31.03 \\
\hline Obese $(\geq 30)$ & 3 & 10.34 \\
\hline Total & 29 & 100 \\
\hline
\end{tabular}

$\mathrm{SD}=$ Standard deviation.

Table 3 describes the proportions of participants having changes in AMH and AFC after ovarian injection of autologous PRP. Tables 4-6 describes the proportions of participants having changes in AMH and AFC after ovarian injection of autologous PRP Injection. Post-PRP AMH changes were significant at second and third cycle monitoring and post-PRP AFC changes were significant at all first, second and third cycle observations.

Three women (10.34\%) got pregnant. Two women got pregnant spontaneously in third month after PRP injection. One woman got pregnant by ovarian stimulation and intrauterine insemination (IUI) in the third cycle, done when AMH increased from 0.42 to $0.61 \mathrm{ng} / \mathrm{ml}$. 
Table 3: Number and percentage of population having changes in ovarian reserve markers (AMH and AFC) postPRP.

\begin{tabular}{|c|c|c|c|c|c|}
\hline Parameters & $\begin{array}{l}\text { Baseline } \\
\text { Mean } \pm \text { SD }(n=29)\end{array}$ & $\begin{array}{l}\text { At first cycle } \\
(n=29)(\%)\end{array}$ & $\begin{array}{l}\text { At second cycle } \\
(\mathbf{n}=29)(\%)\end{array}$ & $\begin{array}{l}\text { At third cycle } \\
(\mathbf{n}=23)(\%)\end{array}$ & $\begin{array}{l}\text { Mean percentage } \\
(\%)\end{array}$ \\
\hline $\begin{array}{l}\text { AMH } \\
\text { (raised) }\end{array}$ & $\begin{array}{l}0.32 \pm 0.16(29) \\
0.31 \pm 0.17(23) \\
\text { (after drop out) }\end{array}$ & $\begin{array}{l}17 / 29 \\
(58.62)\end{array}$ & $\begin{array}{l}25 / 29 \\
(86.21)\end{array}$ & $\begin{array}{l}21 / 23 \\
(91.30)\end{array}$ & 78.71 \\
\hline $\begin{array}{l}\text { AFC } \\
\text { (raised) }\end{array}$ & $\begin{array}{l}3.41 \pm 0.73(29) \\
3.30 \pm 0.76(23) \\
\text { (after drop out) }\end{array}$ & $\begin{array}{l}16 / 29 \\
(55.17)\end{array}$ & $\begin{array}{l}23 / 29 \\
(79.31)\end{array}$ & $\begin{array}{l}22 / 23 \\
(95.65)\end{array}$ & 76.71 \\
\hline
\end{tabular}

Table 4: Changes of AMH and AFC (baseline versus first cycle post-PRP values (n=29).

\begin{tabular}{|c|c|c|c|c|c|c|}
\hline \multirow{2}{*}{ Parameters } & \multirow{2}{*}{$\begin{array}{l}\text { Baseline } \\
\text { mean } \pm \text { SD }\end{array}$} & \multirow{2}{*}{$\begin{array}{l}\text { First cycle post- } \\
\text { PRP mean } \pm \text { SD }\end{array}$} & \multirow{2}{*}{$\begin{array}{l}\text { Difference of } \\
\text { mean } \pm \text { SD }\end{array}$} & \multicolumn{2}{|c|}{$\begin{array}{l}95 \% \text { CI of mean } \\
\text { difference }\end{array}$} & \multirow{2}{*}{$P$ value } \\
\hline & & & & Lower & Upper & \\
\hline AMH (ng/dl) & $0.32 \pm 0.16$ & $0.37 \pm 0.14$ & $\begin{array}{l}0.04 \pm 0.15 \\
\text { (increased) }\end{array}$ & 0.01 & 0.10 & 0.119 \\
\hline AFC (number) & $3.41 \pm 0.73$ & $4.76 \pm 2.06$ & $\begin{array}{l}1.34 \pm 1.89 \\
\text { (increased) }\end{array}$ & 0.62 & 2.06 & 0.001 \\
\hline
\end{tabular}

Table 5: Changes of AMH and AFC (baseline versus second cycle post-PRP values (n=29).

\begin{tabular}{|lllllll|}
\hline Parameters & $\begin{array}{l}\text { Baseline } \\
\text { mean } \pm \text { SD }\end{array}$ & $\begin{array}{l}\text { Second cycle post- } \\
\text { PRP mean } \pm \text { SD }\end{array}$ & Difference & \multicolumn{2}{l}{$\begin{array}{l}\text { 95\% CI of mean } \\
\text { difference }\end{array}$} & P value \\
\hline AMH (ng/d) & $0.32 \pm 0.16$ & $0.51 \pm 0.24$ & $\begin{array}{l}0.18 \pm 0.21 \\
\text { (increased) }\end{array}$ & 0.10 & 0.26 & 0.000 \\
\hline AFC (number) & $3.41 \pm 0.73$ & $5.59 \pm 1.76$ & $\begin{array}{l}2.17 \pm 1.71 \\
\text { (increased) }\end{array}$ & 1.52 & 2.82 & 0.000 \\
\hline
\end{tabular}

Table 6: Changes of AMH and AFC (baseline versus third cycle post-PRP values(n=23).

\begin{tabular}{|lllllll|}
\hline Parameters & $\begin{array}{l}\text { Baseline } \\
\text { mean } \pm \text { SD }\end{array}$ & $\begin{array}{l}\text { Third cycle post- } \\
\text { PRP mean } \pm \text { SD }\end{array}$ & Difference & \multicolumn{2}{l}{$\begin{array}{l}\text { 95\% CI of mean } \\
\text { difference } \\
\text { Lower }\end{array}$} & Upper \\
\hline AMH (ng/dl) & $0.31 \pm 0.17$ & $0.51 \pm 0.21$ & $\begin{array}{l}0.20 \pm 0.16 \\
\text { (increased) }\end{array}$ & 0.14 & 0.27 & 0.000 \\
\hline AFC (number) & $3.30 \pm 0.76$ & $6.70 \pm 1.96$ & $\begin{array}{l}3.39 \pm 2.06 \\
\text { (increased) }\end{array}$ & 2.50 & 4.28 & 0.000 \\
\hline
\end{tabular}

$\mathrm{AMH}=$ Anti-mullerian hormone; $\mathrm{AFC}=$ antral follicle count; $\mathrm{SD}=$ standard deviation; $\mathrm{PRP}=$ platelet rich plasma.

\section{DISCUSSION}

POR can be defined as a reduction in quantity and quality of oocytes in women of reproductive age group. ${ }^{1}$ Bologna criteria has been introduced following the consensus meeting of ESHRE working group on poor ovarian reserve definition held in 2011. Accordingly at least two of the following three features are needed for diagnosis of POR: advance maternal age ( $\geq 40$ years) or any of the risk factors for POR; a previous poor ovarian response ( $\leq$ three oocytes with a conventional stimulation protocol); and an abnormal ovarian reserve test (i.e. AFC: $5-7$ follicles or AMH: $0.5-1.1 \mathrm{ng} / \mathrm{ml}) .{ }^{14}$ In this study AMH level $\leq 0.5$ $\mathrm{ng} / \mathrm{ml}$ and $\mathrm{AFC} \leq 4$ in both ovaries were considered as POR.
Mean age of the study population was $35.90 \pm 3.20$ years and more than half of the study population belonged to 30 35 years age. Socio-economic status is an important social determinant that can have profound impacts on reproductive health. In this study, it was observed that almost two-third $(62.07 \%)$ of the population was from lower middle (6827.79-26857.99 taka/month) socioeconomic status, $34.48 \%$ were from middle (26858.0083018.22 taka/month) socio-economic status and only $3.45 \%$ were from higher (>83018.22 taka/month) socioeconomic class. Surekha et al revealed that higher socioeconomic status is significantly associated with better ovarian reserve. ${ }^{15}$ Low socioeconomic status aggravate stress, under nutrition and financial hardships that may affect ovarian reserve. Higher socioeconomic status have easier access to health care as well as better control over 
their reproductive health in comparison to people living in communities with a lower socioeconomic status. Almost two-third $(65.52 \%)$ of our women were housewife and more than one-third (337.93\%) of the women had less than 10 years education. So most of our women, with poor education and empowerment are disadvantaged regarding autonomy in decision-making and gaining access to economic resources, factors with serious impact on fertility management. ${ }^{16}$

This quasi experimental study was carried out with an aim to evaluate the effect of autologous PRP on AMH and AFC in sub fertile women with poor ovarian reserve. The present study findings are discussed and compared with previously published relevant studies.

Callejo et al reported the case of a woman without ovaries, who had spontaneous menstruation four and half months after injection of PRP into transplanted frozen-thawed ovarian tissue. ${ }^{9}$ After successful drug stimulation, she had good quality eggs and through an IVF trial, she got pregnant. Pantoset al showed that ovarian rejuvenation and folliculogenesis reactivation occurred in peri-menopausal women after autologous platelet-rich plasma treatment. ${ }^{10}$ Sills et al conducted a prospective clinical trial on 182 women with low ovarian reserve with mean age $45 \pm 6.1$ years and (pre-treatment) mean AMH level $0.34 \pm 0.08$ ng/ml. ${ }^{17}$ AMH, FSH and serum estradiol data were recorded at two weeks interval post PRP and compared to baseline (pre-PRP) values. Evidence of improved ovarian function was noted in all who received intra-ovarian PRP, as early as two months after treatment. The change in AMH was statistically significant $(p<0.03)$, though the mean age was higher and mean $\mathrm{AMH}$ was lower than this study.

Melo et al conducted a prospective controlled, nonrandomized comparative study in Venezuela on 46 women with low ovarian reserve prior to assisted reproductive technology (ART). ${ }^{12}$ The mean BMI was $24.6 \pm 1.2 \mathrm{~kg} / \mathrm{m}^{2}$, within normal limit as like present study. They investigated the impact of a 3- month course of intra cortical injections of autologous PRP upon ovarian reserve markers versus no intervention in women with low ovarian reserve. Women with abnormal ovarian reserve markers (FSH, AMH, and AFC) were allocated to one of the following groups according to patients' choice: monthly intra-cortical ovarian PRP injections for three cycles or no intervention. At the 3 months follow-up, women treated with PRP experienced a significant improvement in $\mathrm{FSH}$, $\mathrm{AMH}$ and AFC whereas there was no change in the control group. The findings of this study are in accordance with Melo et al who found significant $(\mathrm{p}<0.001)$ improvement of post-PRP, AMH level at three month of ovarian PRP in $63.00 \%$ of participants. ${ }^{12}$ AFC on ultrasound following PRP treatment increased in $75.00 \%$. FSH level dropped in $33.00 \%$ of the women receiving PRP. The change was significant $(\mathrm{p}<0.001)$.
Sfakianoudis et al conducted four pilot studies on POR, premature ovarian insufficiency, peri-menopause and menopause respectively in Greece to provide pilot data regarding PRP application for ovarian rejuvenation. ${ }^{13}$ They enrolled 30 women with premature ovarian insufficiency, mean age $35.22 \pm 1.57$ years and 29 peri-menopausal women, mean age $43.25 \pm 1.42$ years. The mean BMI was $23.12 \pm 2.52 \mathrm{~kg} / \mathrm{m}^{2}$, within normal range as was ours (mean BMI was $23.50 \pm 3.30 \mathrm{~kg} / \mathrm{m}^{2}$ ). A significant improvement on the hormonal profile and the ovarian reserve status was noted in all four groups, along with improved intracytoplasmic sperm injection (ICSI) cycle performance after PRP injection. The pre- PRP mean AMH was $0.18 \pm 0.04 \mathrm{ng} / \mathrm{ml}$ and post treatment mean at first, second and third cycle was $0.53 \pm 0.10 \mathrm{ng} / \mathrm{ml}$; $0.65 \pm 0.08 \mathrm{ng} / \mathrm{ml}$ and $0.75 \pm 0.06 \mathrm{ng} / \mathrm{ml}$ respectively, a rise which was statistically significant $(\mathrm{p}<0.001)$. The pretreatment AFC was zero (0) and post treatment mean \pm SD at first, second and third month was $1.56 \pm 0.51,2.06 \pm 0.73$ and $2.33 \pm 0.49$ respectively, an increase which was statistically significant $(\mathrm{p}<0.001)$. The pre-treatment mean of FSH was $40.61 \pm 6.05 \mathrm{mIU} / \mathrm{ml}$ and post treatment mean at first, second and third month was $35.87 \pm 4.77 \mathrm{mIU} / \mathrm{ml}$, $27.18 \pm 5.82 \mathrm{mIU} / \mathrm{ml}$, and $20.67 \pm 3.58 \mathrm{mIU} / \mathrm{ml}$ respectively, the reduction in all three cycle were statistically significant $(p<0.001)$. The findings are in agreement with that of our study.

Chakiroglu et al conducted a multi-center study in United States of America (USA) and Turkey on more than 300 women with premature ovarian insufficiency. ${ }^{18}$ The mean age was $34.8 \pm 4.4$ years, with mean duration of infertility was $6.8 \pm 4.9$ years in accordance to our study (mean duration of infertility $6.80 \pm 3.0$ years). Their objective was to determine whether intra-ovarian injection of autologous PRP improves response to ovarian stimulation and IVF outcome in women with primary ovarian insufficiency (POI). They found that $64.8 \%$ participants had improved AFC after ovarian PRP exposure, statistically significant $(p<0.05)$ change similar to our study.

Salih al conducted a randomized clinical trial on 51 Sudanese sub fertile women with AMH level $<0.5 \mathrm{ng} / \mathrm{ml}$ to explore if laparoscopic ovarian autologous PRP injection has favourable effect on AMH levels. ${ }^{11}$ AMH level of every participant was measured before and 3 months after administration of PRP. AMH level increased post-PRP in $33.30 \%$ of the participants. The change was highly significant $(<0.001)$. They also showed that $7.84 \%$ of their women got pregnant after ovarian PRP injection. In accordance with them $10.34 \%$ of our women got pregnant during study period.

Most of the studies injected the PRP in the ovaries transvaginally under sonographic guidance. The first case report and few studies like Salih et al used the laparoscopic approach. ${ }^{9,11}$ Our study injected the PRP in ovaries under laparoscopic guidance. Infertile women with poor ovarian reserve at BSMMU who are reluctant to undergo IVF due to financial constraints and psychosocial inhibition were 
recruited as study population. Laparoscopic evaluation of tubo-peritoneal factors and ovarian injection of PRP at the same time was a reasonable alternative for them though probability of pregnancy was not adequately defined. The women were selected for laparoscopic pelvic organ evaluation as infertility work up. We availed the opportunity to inject PRP during laparoscopy.

For some women there are reasons for postponing pregnancy in early age, such as education, career and late marriage. There may be age related decline in ovarian reserve, with poor response to ovarian stimulation. In addition there are women with primary ovarian insufficiency due to known or unknown causes. There is no effective therapy to augment their own ovarian activity. All these patients wish to have their own biological child, though oocytes or embryo donation may be the only proven methods in their treatment. Ovum or embryo donation procedure is not acceptable in our country due to ethical and religious barriers. Many of them are desperate enough to go abroad for such third party reproduction. Ovarian rejuvenation with platelet rich plasma may be a good option for these women to regenerate follicles with the hope to improve the oocyte quality and ovarian reserve and reduce the need of ovum donation in ART procedure. Some infertile women who not able to bear the huge cost of IVF will be able to try for pregnancy spontaneously or by IUI if ovarian reserve can be increased by PRP therapy.

\section{Limitations}

The study is not without limitations. The study population was selected from one selected hospital in Dhaka city, so that results of the study may have poor external validity. The self-controlled quasi experimental study with convenient sampling was conducted with a small sample size over a very short period of time without randomization. Data collection and follow up was challenging due to COVID-19 situation, dropout rate was comparatively high.

\section{CONCLUSION}

The injection of autologous PRP into human ovaries is a safe procedure to improve ovarian reserve markers (AMH and AFC) in women with poor ovarian reserve. After verifying these preliminary results in larger population with multiple ethnic groups and follow up for longer duration ovarian injection of PRP could be used as a treatment for the ovarian regeneration and the folliculogenesis reactivation in women with poor ovarian reserve. Interventional studies like randomized control trials are needed to establish the effective relationship of ovarian PRP with ovarian reserve markers.

\section{Funding: No funding sources} Conflict of interest: None declared

Ethical approval: The study was approved by the Institutional Ethics Committee

\section{REFERENCES}

1. Jirge RP. Poor ovarian reserve. J Hum Reprod Sci. 2016;9(2):1-13.

2. Zukerman $\mathrm{S}$. The number of oocytes in the mature ovary. Rec Prog Horm Res. 1951;6:63.

3. Johnson J, Canning J, Kaneko T, Pru JK, Tilly JL. Germline stem cells and follicular renewal in the postnatal mammalian ovary. Nature. 2004;428:145-50.

4. Tilly JL, Telfer EE. Purification of germinal stem cells from adult mammalian ovaries: a step closer towards control of the female biological clock. Mol Hum Reprod. 2010;15:393-8.

5. Niikura Y, Niikura T, Tilly JL. Aged mouse ovaries possess rare premeiotic germ cells that can generate oocytes following transplantation into a young host environment. Aging. 2009;1:971-8.

6. Anitua E, Andia I, Ardanza B, Nurden P, Nurden AT. Autologous platelets as a source of proteins for healing and tissue regeneration .Thromb Haemost. 2004;91:4-15.

7. Foster TE, Puskas BL, Mandelbaum BR, Gerhardt MB, RodeoSA. Platelet-rich plasma: from basic science to clinical applications. Am J Sport Med. 2009;37:2259-72.

8. Amable PR, Carias RB, Teixeira MB, Pacheo IC, Amaral RJFC, Granjeiro JM et al. Platelet rich plasma preparation for regenerative medicine: optimization and quantification of cytokines and growth factors. Stem Cell Res Ther. 2013;4(67):1-13.

9. Callejo J, Salvador C, Gonzalez- Nunez S, Almeida L, Rodriguez L. Live birth in a woman without ovaries after autograft of frozen-thawed ovarian tissue combined with growth factors. J Ovarian Res. 2013;6(33):1-6.

10. Pantos K, Nitsos N, Kokkali G, Vaxevanoglou T, Marcomichali C, Pantou A, et al. Ovarian rejuvenation and folliculogenesis reactivation in perimenopausal women after autologous platelet-rich plasma treatment. Proceedings of the 32nd Annual Meeting of ESHRE; 2016 July 3-6; Helsinki, Finland. Hum Reprod. 2016;1:301.

11. Sills ES, Rickers NS, Li X, Palermo GD. First data on in vitro fertilization and blastocyst formation after intraovarian injection of calcium gluconate- activated autologous platelet rich plasma. Gynecol Endocrinol. 2018;28:1-5.

12. Salih MA, Hossein OM, Aldin AT, Hamad MN, et al. Correlation between antimullerian hormone level before and after laparoscopic ovarian autologous PRP injections. Evid Based Women's Health J. 2019;10(1):89-94.

13. Melo P, Navarro C, Jones C, Coward K, Coleman L. The use of autologous platelet - rich plasma (PRP) versus no intervention in women with low ovarian reserve undergoing fertility treatment: a nonrandomized interventional study. J Assist Reprod Genet. 2020;37:55-863. 
14. Sfakianoudis K, Simopoulou M, Grigoriasdia S, Panttou A, et al. Reactivating ovarian function through autologous platelet-rich plasma intraovarian infusion: pilot data on premature ovarian insufficiency, perimenopausal, menopausal and poor responder women. J Clin Med. 2020;9(1829):1-25.

15. Ishrat S, Deeba F, Anwary SA, Banu J. Correlation and discordance of anti-mullerian hormone with follicle stimulating hormone in infertile women with premature ovarian insufficiency and diminished ovarian reserve. Int $\mathbf{J}$ Reprod Contracept Obstet Gynecol. 2021;10(1):32-8.

16. Ferrareti AP, La Marca A, Fauser BC, Tarlatzis B, Nargund G, Gianaroli I. ESHRE Working Group on Poor Ovarian Response Definition. ESHRE consensus and the definition of 'poor response' to ovarian stimulation for in vitro fertilization: The Bologna Criteria. Hum Reprod. 2011;26:1616-24.
17. Surekha T, Himabindu Y, Sriharibabu M. Impact of socio-economic status on ovarian reserve markers. J Hum Reprod Sci. 2013;6(3):201-4.

18. Cakiroglu Y, Saltik A, Yuceturk A, Karaosmanoglu O, Kopuk SY, et al. Effect of intra-ovarian injection of autologous platelet rich plasma on ovarian reserve and IVF outcome parameters in women with primary ovarian insufficiency. Aging Res. 2020;12(11):10211-21.

Cite this article as: Uddin MJ, Banu J, Ishrat $\mathrm{S}$, Sultana S, Munira S, Shume MM, Huda SF. Effect of autologous platelet rich plasma on anti-mullerian hormone and antral follicle count in sub fertile women with poor ovarian reserve. Int J Reprod Contracept Obstet Gynecol 2022;11:292-8. 